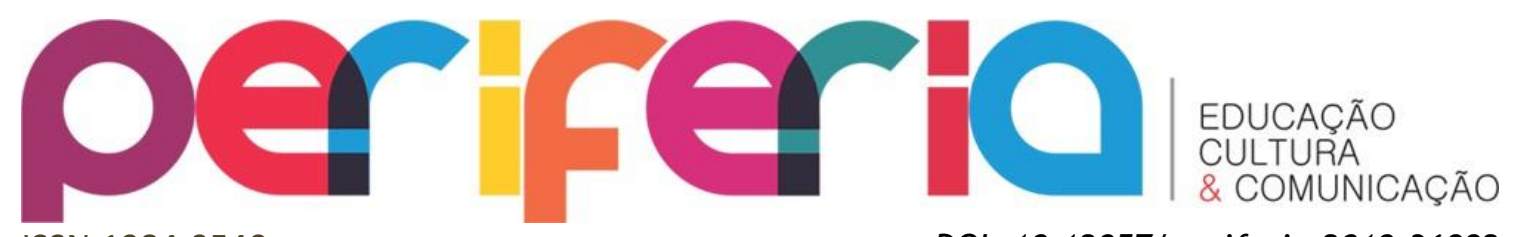

\title{
'BRACE YOURSELVES, THE ZUERA IS COMING'1: MEMES, LETRAMENTO MIDIÁTICO DIGITAL E APROPRIAÇÃO CRIATIVA DOS FÃ̃S DE GAME OF THRONES NO FACEBOOK
}

\author{
Luana Inocêncio ${ }^{2}$ \\ Universidade Federal Fluminense \\ Davi Rebouças ${ }^{3}$ \\ Universidade Federal Fluminense
}

\section{Resumo}

Ao investigar como os processos interacionais e de sociabilidade se relacionam com práticas de literacia midiática digital e aprendizagem social nas comunidades online (KNOBEL; LANKSHEAR, 2007), este artigo analisa os diálogos intertextuais nos memes em comentários da página Game of Thrones da Depressão no Facebook, que se utilizam do humor para estruturar coletivamente uma experiência lúdica de consumo, letramento e ressignificação com relação ao produto cultural. A partir de um conjunto de termos e metáforas que são frequentemente referenciados nestes memes da série, um imaginário específico é compartilhado, reconhecido e intensamente apropriado pelos interagentes, constituindo uma rica amostra da intimidade dos fãs com o universo narrativo do programa. Conclui-se que, enquanto micronarrativas que aglutinam saberes de variados campos (ESCALANTE, 2016), os memes de internet envolvem os interagentes em novas práticas criativas de sociabilidade que podem ser compreendidas como literacias - ou letramentos midiáticas (XAVIER, 2005), posto que nas comunidades digitais são demandadas aos “insiders" certas proficiências (SHIFMAN, 2013; JENKINS, 2008). Destacam-se ao longo desta análise de conteúdo: letramentos com relação às materialidades das TICs nestas plataformas (ferramentas, interfaces); suas usabilidades sociais (“curtir” postagens, responder comentários, marcar usuários, compartilhar posts com nova legenda descritiva adicionada) e conhecimento intertextual (compreensão metalinguística, reconhecer piadas e referências com relação ao universo mencionado, desenvolver novas apropriações destas aplicando variados

\footnotetext{
10 título do trabalho faz referência ao popular meme do seriado Game of Thrones, o "Brace Yourselves, Winter is Coming", algo como "Preparem-se, o inverno está vindo", cena protagonizada por Lorde Ned Stark na primeira temporada. No meme, o termo winter - inverno - é substituído por alguma outra palavra para anunciar a sua chegada iminente e altamente temida ou mesmo ansiada (<http://goo.gl/VohLmK>). Já o termo zuera, foi apropriado da emblemática frase the zuera never ends, que se tornou uma expressão brasileira popularizada nos sites de redes sociais e equivale a "a zoeira nunca tem fim", geralmente aplicada a situações em que interagentes descontextualizam alguma situação séria, transformando-a em algo engraçado, frequentemente por meio de memes.

2 Professora de Publicidade e Propaganda na Universidade Federal Fluminense. Doutoranda em Comunicação pela Universidade Federal Fluminense (PPGCOM/UFF). Pesquisadora do Laboratório de Pesquisa em Culturas Urbanas e Tecnologias da Comunicação (LabCult/UFF) e do Grupo de Pesquisa em Retórica do Consumo (ReC/UFF). E-mail: luanahinocencio@hotmail.com

${ }^{3}$ Doutorando em Mídia e Cotidiano pela Universidade Federal Fluminense (PPGMC/UFF). Mestre em Linguística Aplicada pela Universidade Estadual do Ceará.
} 


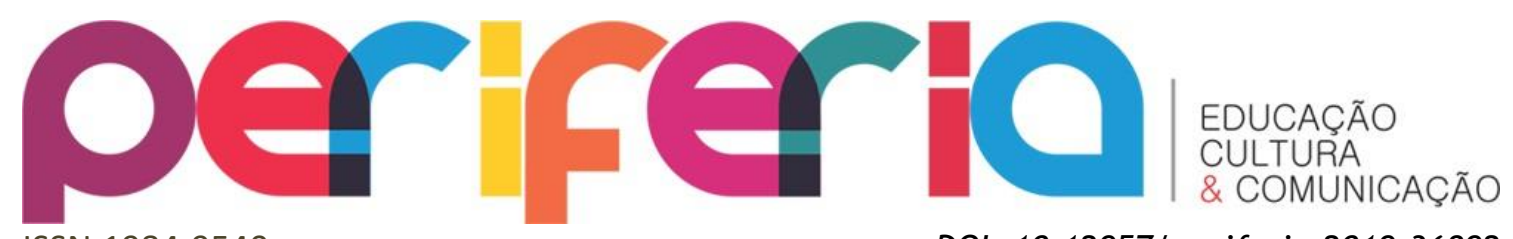

ISSN:1984-9540

textos, recursos gráficos e audiovisuais). Neste sentido, percebeu-se a necessidade de reflexões acerca destes múltiplos letramentos nos processos de aprendizagem social em comunidades online, relacionados ao hibridismo de diferentes formas de linguagem nos sites de redes sociais.

Palavras-chave: Meme; cultura dos fãs; letramento midiático digital; Facebook.

\title{
'BRACE YOURSELVES, THE ZUERA IS COMING': MEMES, DIGITAL MEDIA LITERACY AND CREATIVE APPROPRIATION OF GAME OF THRONES FANS ON FACEBOOK
}

\begin{abstract}
In investigating how interactional and sociability processes relate to practices of digital media literacy and social learning in online communities (KNOBEL; LANKSHEAR, 2007), this article analyzes the intertextual dialogues in memes in comments on the Game of Thrones da Depressão page on Facebook, which use humor to collectively structure a playful experience of consumption, literacy and resignification in relation to the cultural product. From a set of terms and metaphors that are often referenced in these memes of the series, a specific imagery is shared, recognized, and intensely appropriated by the interacting agents, constituting a rich sample of the intimacy of the fans with the narrative universe of the program. It is concluded that, as micronarratives that agglutinate knowledge of various fields (ESCALANTE, 2016), internet memes involve the interacting agents in new creative practices of sociability that can be understood as literacies - or media literacies (XAVIER, 2005), post that in digital communities certain insights are demanded from the insiders (SHIFMAN, 2013; JENKINS, 2008). Throughout this content analysis, we highlight: literacies related to the materialities of ICTs in these platforms (tools, interfaces); their social usability ("like" posts, respond to comments, mark users, share posts with new added descriptive legend) and intertextual knowledge (understanding metalinguistics, recognizing jokes and references with respect to the aforementioned universe, developing new ones using different texts, and audiovisual). In this sense, the need for reflections about these multiple literacies in the processes of social learning in online communities, related to the hybridity of different forms of language in the social networking sites was perceived.
\end{abstract}

Keywords: Meme; fan culture; digital media literacy; Facebook. 


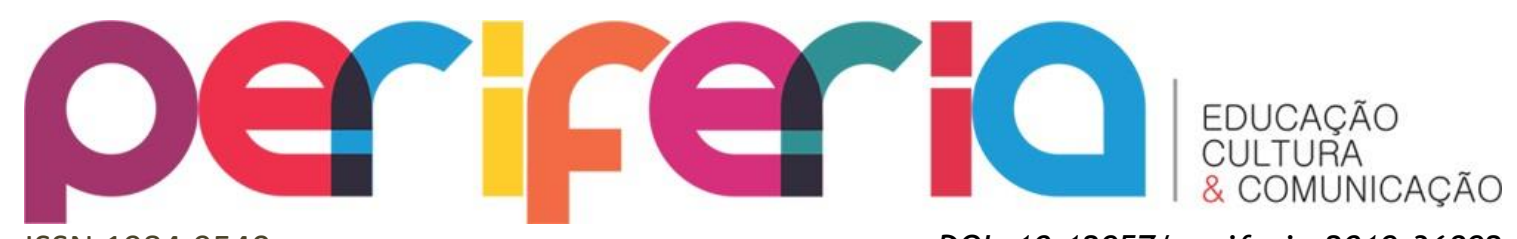

\section{'BRACE YOURSELVES, THE ZUERA IS COMING' : MEMES, LETRA MIDIÁTICA DIGITAL Y LA APROPIACIÓN CREATIVA DE LOS FANS DE GAME OF THRONES EN FACEBOOK}

\section{Resumen}

En este artículo se analizan los diálogos intertextuales en los memes en comentarios de la página Game of Thrones da Depressão en Facebook, en el que se analizan cómo los procesos interactivos y de sociabilidad se relacionan con prácticas de alfabetización mediática digital y aprendizaje social en las comunidades online (KNOBEL, LANKSHEAR, 2007), que se utilizan del humor para estructurar colectivamente una experiencia lúdica de consumo, letramento y resignificación con relación al producto cultural. A partir de un conjunto de términos y metáforas a menudo referenciados en estos memes de la serie, un imaginario específico es compartido, reconocido e intensamente apropiado por los interagentes, constituyendo una rica muestra de la intimidad de los fans con el universo narrativo del programa. Se concluye que, mientras que micronarrativas que aglutinan saberes de variados campos (ESCALANTE, 2016), los memes de Internet involucra a los interagentes en nuevas prácticas creativas de sociabilidad que pueden ser comprendidas como literaturas - o letras -mediáticas (XAVIER, 2005), puesto que en las comunidades digitales son demandadas a los "insiders" ciertas proficiencias (SHIFMAN, 2013, JENKINS, 2008). Se destacan a lo largo de este análisis de contenido: letramentos con relación a las materialidades de las TICs en estas plataformas (herramientas, interfaces); (en el caso de que se produzca un cambio en la calidad de la información, en el caso de que se produzca un cambio en la calidad de la información, y audiovisuales). En este sentido, se percibió la necesidad de reflexiones acerca de estos múltiples letras en los procesos de aprendizaje social en comunidades online, relacionados al hibridismo de diferentes formas de lenguaje en los sitios de redes sociales.

Keywords: Meme; alfabetización; cultura de los fans; letra mediática digital; Facebook. 


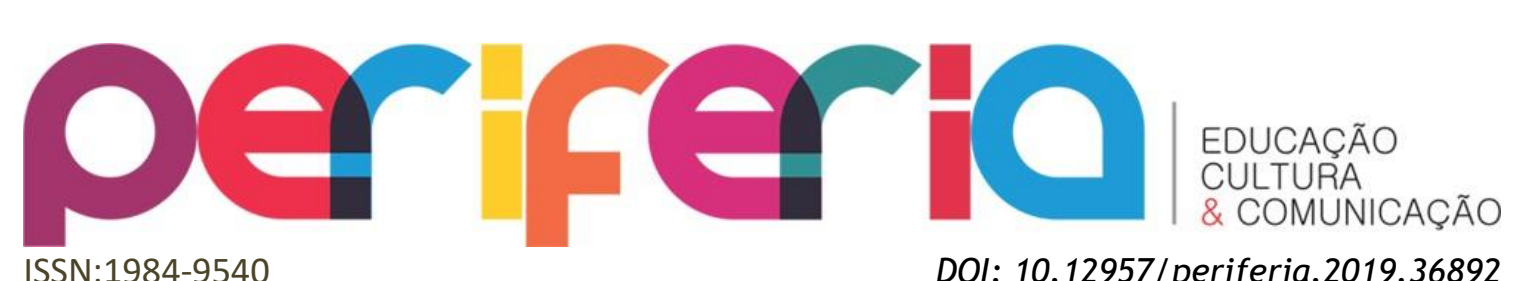

ISSN:1984-9540

DOI: $10.12957 /$ periferia.2019.36892

\section{LETRAMENTO ALÉM DO ENTRETENIMENTO}

Os memes representam um gênero textual e audiovisual que permeia os espaços digitais, podendo ser caracterizados, dessa forma, como hipertextos. A nova ordem mundial, marcada pela Globalização, fez/faz com que o contato com hipertextos seja constante e cada vez mais significativo, dadas as possibilidades experienciais entre o leitor e o texto, graças ao avanço das tecnologias digitais. Evidencia-se, em face desse contexto, a necessidade do desenvolvimento de novas competências por parte dos leitores (no ciberespaço, interagentes).

A noção de letramento, há algum tempo, não mais se restringe ao espaço escolar, apesar de tal perspectiva ainda ser dominante, associada a um ideário de poder na sociedade (STREET, 2014), onde os letrados ocupariam posições privilegiadas. Mais que fluência nas habilidades de ler e escrever, o letramento, atualmente, abarca a habilidade de o sujeito participar das diversas interações sociais de forma apropriada, fluente, consciente, por exemplo, das aplicações de gêneros do discursos apropriadas a cada situação. Os conceitos de letramento, todavia, variam conforme as culturas, tornando restrita uma contextualização que abarque diversos contextos e práticas (XAVIER, 2005). Surgem, então, os letramentos específicos, como o letramento digital e o letramento hipertextual.

O letramento digital, mais frequentemente e apropriadamente denominado como literacia, não deve ser entendido como o mero domínio de um conjunto de técnicas de manuseio de aparelhos digitais. Somado a isso, há a necessidade de dominar as diversas práticas sociais do ambiente digital, permeado por hipertextos, e suas múltiplas possibilidades de construção textual, interação e modalidade. Lobo-Sousa et al (2009) corroboram a compreensão de que o letramento hipertextual seria, então, uma categoria do letramento digital.

Mais que viabilizar o uso de novas tecnologias digitais para entretenimento, o domínio das normas de utilização das tecnologias de comunicação e informação e das formas de (re)construção de sentidos e semioses, a partir dos aparatos tecnológicos, permite o desenvolvimento de novas habilidades, competências e conhecimentos. O letrado digital conta, assim, com a possibilidade de expandir 


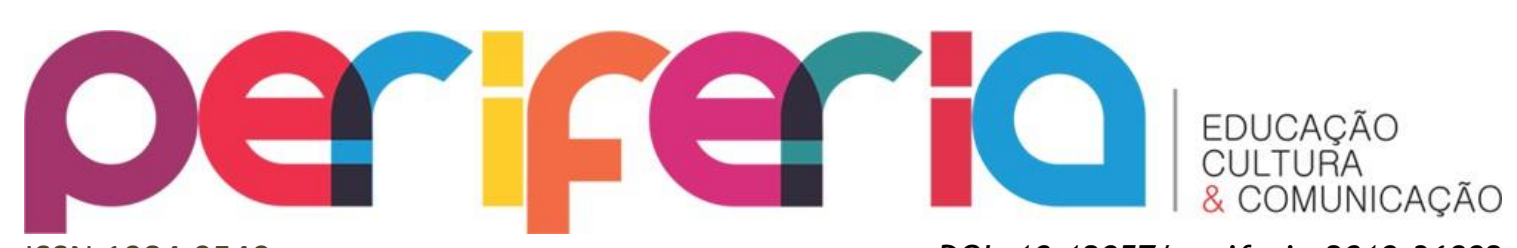

ISSN:1984-9540

seus outros letramentos, inclusive o formal/tradicional. Isso, contudo, depende de um olhar mais crítico sobre o uso das TICs, a fim de que haja reconhecimento e apropriação de suas funções e predicados na promoção de um conhecimento contextualizado às práticas contemporâneas.

Assim, prospera - e ratifica-se - o entendimento de Street (2014) de que o engajamento no letramento é um ato social. Ao dispor-se a promover o uso apropriado de aparatos digitais, mais que atualizar as metodologias de ensino, lança-se mão de uma aprendizagem mais significativa, inserida na realidade cibercultural. Para isso, torna-se necessário um reconhecimento acerca dos sentidos e impactos dos ambientes digitais na vida dos educandos, como estes se valem das informações encontradas nesses espaços, além de compreender como se dá a interação com os outros interagentes. Uma delas, como discutido anteriormente, é por meio dos memes.

Familiar aos educandos, os memes são possíveis de serem adotados como ferramenta de ensino e aprendizagem ao propor, a partir desse gênero discursivo, novas reflexões sobre o fato gerador do meme e suas implicações sociais e culturais. Em contato com os interlocutores, os enunciados meméticos ganham novos sentidos, novas aplicações e, inclusive, modificam sua materialidade verbal e/ou visual. Evocam-se e movimentam-se, assim, diferentes tipos de conhecimentos para que isso ocorra. Pode-se mencionar ao menos três tipos de conhecimentos que se articulam na construção e interpretação textual: linguístico, enciclopédico ou de mundo e interacional. 0 primeiro diz respeito ao domínio sobre as regras da língua; o segundo, aos conhecimentos formais e informais adquiridos pelo indivíduo ao longo de sua trajetória de vida, incluindo no relacionamento com seus pares; já o interacional refere-se aos conhecimentos que precisam ser mobilizados e ativados quando da interação (CAVALCANTE, 2013).

$\mathrm{Na}$ esteira da abordagem desse aspecto interativo, cabe mencionar o entendimento bakhtiniano de que o destinatário não tem atuação passiva diante do enunciado (BAKHTIN, 2011). Dado o aspecto interativo do ciberespaço, tal assertiva se torna ainda mais relevante. A participação ativa do interlocutor não mais se limita a interpretar e dar novos significados à mensagem, a partir de seu mundo, 


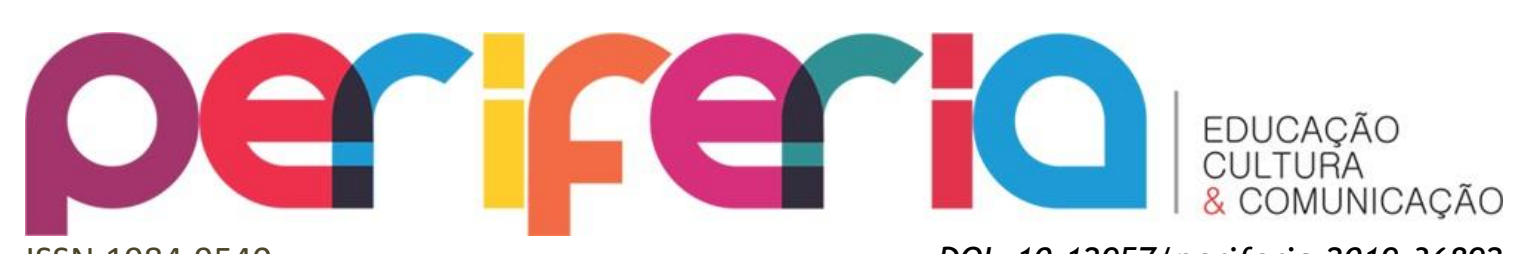

ISSN:1984-9540

de suas experiências de vida, mas em (re)criar e/ou compartilhar a mensagem, demandando, para isso, domínio das ferramentas que tem à disposição, conhecimento enciclopédico, olhar crítico, dentre outras. Cabe a mencionar aqui o letramento midiático, que viabiliza a avaliação e a produção de conteúdos (multi)midiáticos.

Portanto, o reconhecimento da relevância da adoção de diferentes formas de linguagem no ensino não se limita ao desenvolvimento do letramento digital, mas de multiletramentos. Rojo (2012) aponta que os multiletramentos são interativos e colaborativos, quebram e transgridem relações de poder e são híbridos, fronteiriços e mestiços, pois mixam diferentes linguagens, modalidades, mídias e culturas. Xavier (2005) identifica essa aglutinação em hipertextos e a denomina pluritextualidade, acrescentando que os diferentes recursos sígnicos e a junção de diversas linguagens em uma única tela, simultaneamente, "em um mesmo ato de leitura provoca um construtivo, embora volumoso, impacto perceptual-cognitivo no processamento da leitura" (p. 175).

Hibridismo, dinamicidade e flexibilidade de linguagem são palavras-chaves na noção de hipertexto e que dialogam com outras interfaces semióticas (XAVIER, 2005). Tais predicados também são evidentes nos diferentes tipos de letramento, pois, concebendo-se como atos sociais, são alcançados por meio dos diversos conhecimentos partilhados pelas comunidades, que são flexíveis, transformadores e móveis, levando um texto a possuir diferentes construções de sentidos, segundo o repertório dos locutores e dos interlocutores. Portanto, é na circulação e no contato com os Outros que os significados se (re)constroem, podendo ser aceitos ou não pelos grupos em que circulam.

No que segue, serão discutidas reapropriações meméticas feitas por participantes do site de redes sociais Facebook que bem representam a (re)construção e a (re/con)textualização de sentidos. Apesar do evidente foco no entretenimento, o conteúdo que recebe o olhar analítico que será apresentado convida à busca pela compreensão do consumo cultural na atualidade e dos conhecimentos de interesse dos educandos. Além disso, colabora com o 


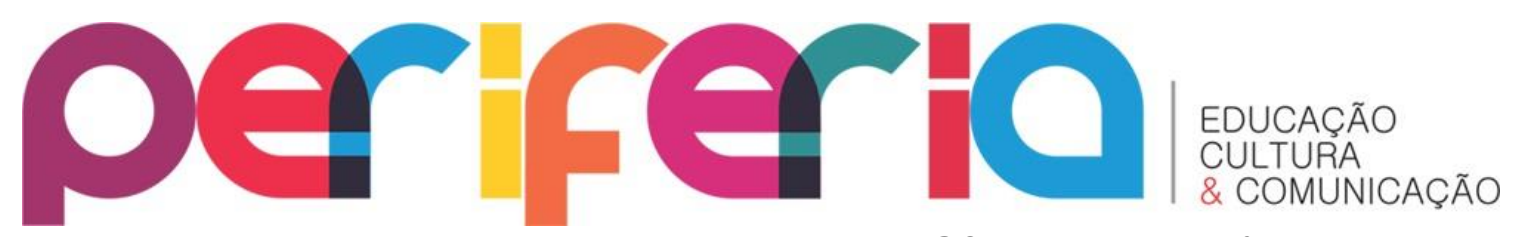

ISSN:1984-9540

DOI: $10.12957 /$ periferia.2019.36892

desenvolvimento de competências acerca do letramento digital e as relacionadas à criatividade.

\section{SITES DE REDES SOCIAIS, CULTURA DOS FÃS E APROPRIAÇÃO DE PRODUTOS MIDIÁTICOS}

A peneira de finalidades e preferências que move o sistema interativo dos sites de redes sociais, ou SRSs, é causadora de grupos mais segmentados. Diferentes públicos se unem para discussões específicas, embebidas por um interesse comum e agregadas a valores apreciados pelo conjunto. As redes sociais abrigam centenas de milhares de agrupamentos de indivíduos unidos por um gosto semelhante. Ao debater sobre as mudanças ocorridas nos últimos anos em torno do panorama epistemológico e empírico dos sites de redes sociais, Ellison e boyd ${ }^{4}$ (2013) revisitam as características mais latentes presentes nas redes sociotécnicas. As autoras destacam a soberania dos laços sociais que rejuntam sujeitos com valores semelhantes em comunidades de gosto, bem como as práticas específicas de apropriação das ferramentas em suas características técnicas, isto é, como são utilizadas na prática, enquanto fatores mais preciosos para a observação que as ferramentas e recursos em si:

O que torna a "mídia social" significativa enquanto uma categoria não é a tecnologia, mas sim a dinâmica sociotécnica que se desenrolou à medida que milhões de pessoas adotaram a tecnologia e a usaram para colaborar, compartilhar informações e socializar. Enquanto isso, os SRSs tornaram-se um gênero de mídias sociais que reduz barreiras à comunicação, facilita a exibição de informações sobre identidade e permite que indivíduos com ideias semelhantes percebam facilmente o seu terreno comum, ajudando assim os usuários a cultivar interações socialmente relevantes (ELLISON; BOYD, 2013, p.160, tradução da autora).

O Facebook, por exemplo, abarca inúmeras páginas dedicadas a admiradores de uma personalidade e/ou produto. Estrategicamente, essas páginas já são

\footnotetext{
${ }^{4}$ Ao citar a autora, preserva-se aqui a sua sistemática preferência em grafar seu nome e sobrenome com iniciais minúsculas, exceto em casos em que a ABNT exige que se destaque a fonte em corpo todo maiúsculo.
} 


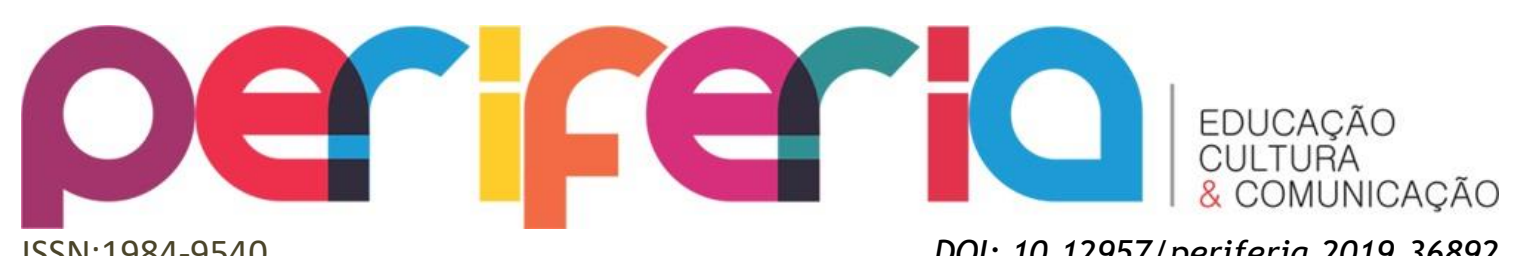

ISSN:1984-9540

DOI: $10.12957 /$ periferia.2019.36892

denominadas fanpages (páginas de fãs) e os interagentes que a curtem, automaticamente são classificados como seus "fãs", mesmo que a curtida seja fruto de uma curiosidade passageira e não de uma intensa busca de aproximação do participante/fã pelo artista/produto/assunto, como parece sugerir o Facebook. Dentro destas páginas, os interagentes podem movimentar as publicações através de curtidas, comentários, compartilhamentos, recomendações, etc.

De acordo com Jenkins (2008, p.181) "os fãs são o segmento mais ativo do público das mídias, aquele que se recusa a simplesmente aceitar o que se recebe, insistindo no direito de se tornar um participante pleno". Esses coletivos enfatizados pelo autor são conhecidos como fandoms, grupos e/ou lugares aproveitados pelos interagentes para o compartilhamento de material associado a determinado produto cultural. Armados pelas correntes do compartilhamento, em homenagem ao mesmo produto, os fãs, por meio de fóruns e sites de relacionamento, reforçados pela similaridade que os rejunta, compõem conexões interativas globais.

A participação é vista como uma parte normal da operação de mídia, e os debates atuais giram em torno das condições dessa participação. Assim como o estudo da cultura dos fãs nos ajudou a compreender as inovações que ocorrem às margens da indústria midiática, podemos também interpretar as estruturas das comunidades de fãs como a indicação de um novo modo de pensar sobre a cidadania e colaboração (JENKINS, 2008, p. 314).

Nessa atmosfera paralela, os participantes elaboram e alastram novidades nas possibilidades encontradas nos relacionamentos em rede, adicionado sentidos específicos as técnicas de comunicação digital. Através dos abundantes recursos conversacionais da ferramenta, os fãs inventam símbolos, aperfeiçoam vocabulários e desenvolvem modos de agir, extremamente valiosos para o restante dos envolvidos no fandom, que buscam produzir e obter insaciadamente mais detalhes sobre o produto que estrutura e motiva a comunidade.

Silveira (2010) destaca a intensidade que as vinculações instituídas nesses espaços possuem. Para o autor, quando um fã escolhe participar de um fandom, ele automaticamente abandona o isolamento sociocultural. Sua ativa contribuição 


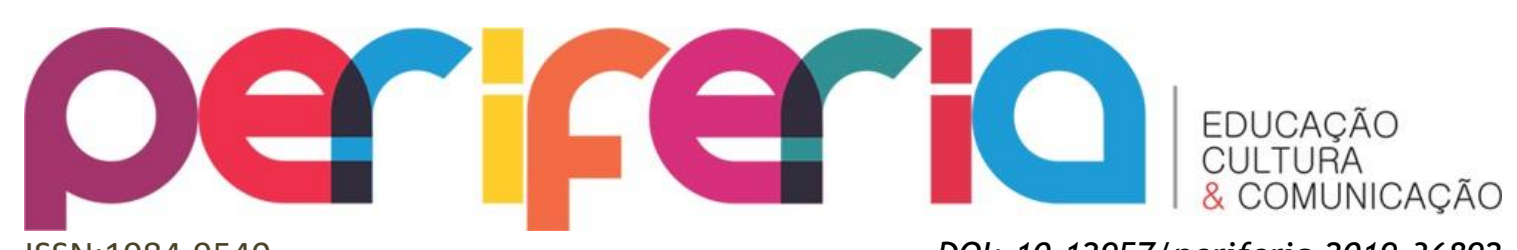

ISSN:1984-9540

DOI: $10.12957 /$ periferia.2019.36892

dentro de um grupo receptivo reforça o senso de pertencimento e lança inovações nas táticas colaborativas da sociedade.

Os fandoms são dotados de associações espontâneas e temporárias, avigorados pelo acesso a conteúdos construídos e repartidos colaborativamente na internet. A interação baseia-se na dedicação emocional e no preparo intelectual, necessários para o andamento das publicações e debates no grupo.

Os fãs diferenciam-se em virtude das finalidades e níveis de participação, porque mesmo aliados por uma teia análoga, cada admirador transporta peculiaridades, a preferência por algum personagem de série de TV exemplifica esse filtro de gostos. Tendo isso em vista, não podemos afirmar que esses espaços interativos sejam exclusivamente centros de públicos homogêneos, envolvidos por idênticas aspirações e condutas. Os fandoms erguem tendências e formam sentidos que movimentam e modificam o convívio social dos indivíduos membros do coletivo.

Nas redes digitais intensamente colaborativas, os atores são vistos cada vez menos como um conjunto de consumidores de conteúdos padronizados, e cada vez mais como indivíduos que estão personalizando, compartilhando e ressignificando conteúdos midiáticos dentro das comunidades online. Quando recíproco, esse processo interacional é denominado por Primo (2013) como interação mútua, uma prática que vai além da ação de um e da efetiva reação de outro, oportunizando as relações que se encadeiam entre os interagentes (em que os diálogos de um afetam os do outro), observando-se a variedade global de comportamentos, aprendizados, referências, cenários sociais, culturais, etc. Essa perspectiva é particularmente elucidativa quando aplicada à forma como os interagentes relacionam-se ativa e reciprocamente, além de colaborativamente, na criação de memes. Utilizando de seus diversos repertórios culturais e gostos pessoais para derivar variadas versões de um mesmo original, podendo este ser especificamente relacionado ao seu contexto local, ainda que compartilhado e decodificado a nível global. 


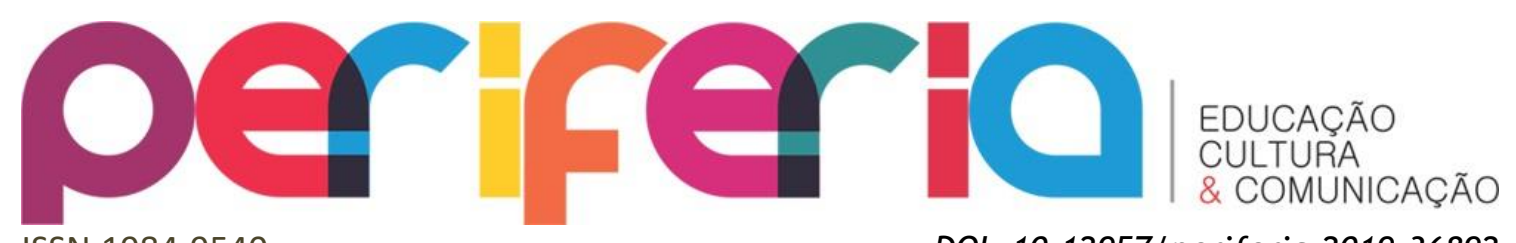

ISSN:1984-9540

DOI: $10.12957 /$ periferia.2019.36892

\section{OS MEMES NA CULTURA DIGITAL: BREVES CONSIDERAÇÕES TEÓRICAS}

Um dos seus primeiros conceitos surgiu em estudos na área da genética, utilizado por Dawkins (1976) para descrever pequenas unidades de cultura, como comportamentos, valores e ideologias, que se espalham de pessoa para pessoa através da cópia ou imitação. Em contraponto, no discurso vernacular dos atores da web, o termo meme é frequentemente usado para descrever a propagação de piadas, boatos, vídeos e sites que se propagam de forma viral na internet.

De acordo com a tríade proposta por Shifman (2013), os memes de internet são unidades de conteúdo digital com características comuns de conteúdo, forma elou postura. De conteúdo, relacionado ao assunto que o vídeo explora; forma: a estrutura estética a que ele obedece; e postura: o posicionamento ideológico que ele assume com relação ao assunto central que é abordado. Cada variação de um meme é elaborada de acordo com o repertório criativo e a discernimento de cada interagente, sendo algumas das três dimensões citadas acima imitadas com bastante similaridade, e outras são alteradas, sendo que a dimensão preservada parece ser o cerne mais bem-sucedido deste meme em específico, no competitivo processo de seleção memética. Eles são, assim, nada mais que uma evolução digital de longas tradições de brincadeiras, humor subversivo, piadas internas e bordões que sempre permearam o imaginário popular.

Um atributo central dos memes digitais é a produção de diferentes versões a partir de um objeto inicial, que são criadas pelos participantes e articuladas como paródias, remixes ou mashups. Estruturadas com interfaces cognitivas flexíveis, plásticas e adaptáveis, algumas plataformas multimidiáticas específicas contribuem para o processo criativo pautado na instantaneidade e característico da cultura participativa, revelando novas possibilidades de produção de sentido e memória coletiva na rede. Conforme lembra Shifman (2013), os memes são mais do que apenas um passatempo divertido ou piadas simples, mas fazem parte de um folclore pós-moderno, uma cultura compartilhada de participação online. Como são artefatos da cultura pop, eles podem fornecer insights sobre como assuntos 


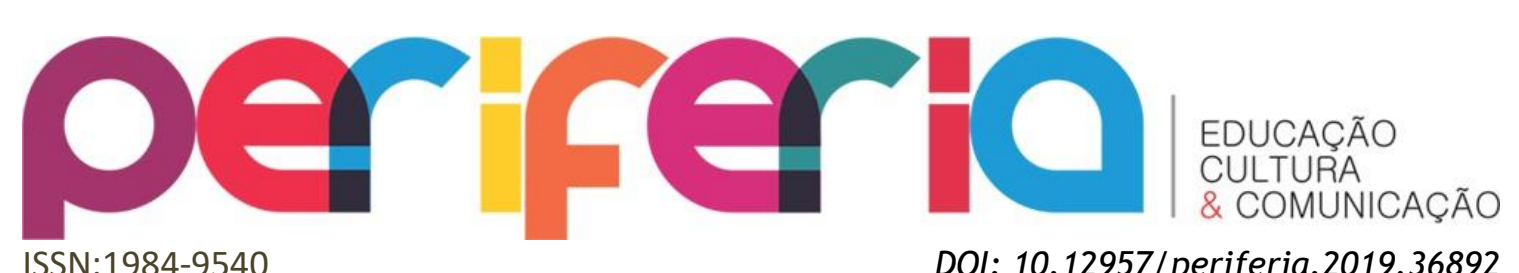

ISSN:1984-9540

DOI: 10.12957/periferia.2019.36892

cotidianos da mídia se entrelaçam com discursos públicos, representando identidades sociais e acontecimentos políticos.

Com o fenômeno memético, mas não só a partir dele, se descortina uma cultura audiovisual amadora guiada pela reapropriação, principalmente a partir das facetas recombinantes da web. Um meme pode assumir o formato de um vídeo, uma imagem estática ou animada em GIF, um elemento verbal como gírias, bordões e hashtags. Exemplos dessa amplitude podem ser encontrados no \#MUSEUdeMEMES 5 , um webmuseu brasileiro que cataloga e analisa memes de várias naturezas, buscando rastrear suas origens.

Nesse cenário, em junho de 2013, o Facebook passou a permitir a inserção de imagens em comentários nas postagens. A nova funcionalidade foi recebida com grande empolgação pelos interagentes, que já passaram a dar um contexto memético aos seus comentários, adicionando uma série de imagens com a conhecida linguagem humorística e divertida. O novo hábito tornou-se presente tanto em perfis pessoais, quanto em fanpages. Com a popularidade desse novo uso possível, diversos blogs passaram a ensinar e disponibilizar fotos com frases engraçadas para postar nos comentários, dentre eles o YouPix.

Em uma postagem com dezenas de comentários, a predominância imagética nos comentários com fotos em comparação com aqueles em que há só texto, parece de fato atrair o olhar dos interagentes. Uma imagem pode potencializa a relevância de um comentário, que ganha vários "curtir", e também a vontade do "comentador com imagens" de emplacar outras interferências de sucesso como esta. Além de trazer maior liberdade para as interações no site, essa novidade realça a presença da ironia e do humor que os participantes brasileiros têm demonstrado que adoram produzir e consumir na internet. Agora que o Facebook conta também com o recurso de adição de imagens aos seus comentários e um público cada vez mais participativo e engajado para disseminar suas ideias dentro de seu círculo de amigos ou mesmo para desconhecidos, é possível identificar um grande potencial cada vez mais interativo.

${ }^{5}$ Disponível em: <http://www.museudememes.com.br/>. Acesso em: 22 ago. 2018.

Periferia, v. 11, n. 2, p. 153-177, maio/ago. 2019 


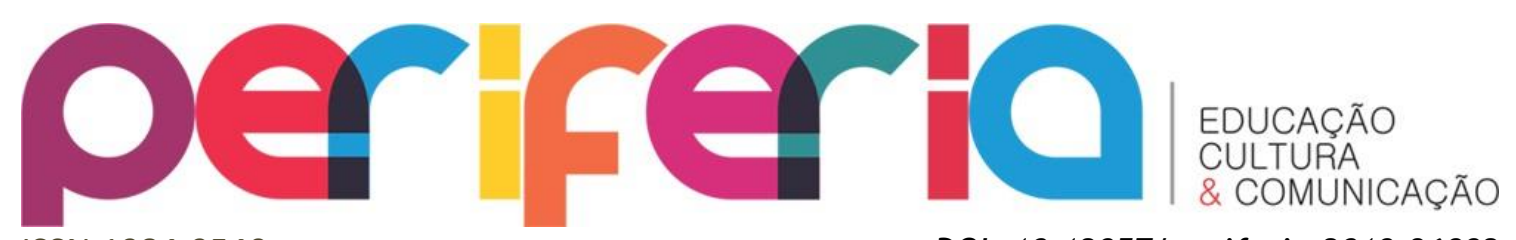

ISSN:1984-9540

DOI: 10.12957/periferia.2019.36892

Uma área de estudos cada vez mais trabalhada sobre os memes versa sobre seu potencial de letramento digital, enquanto um artefato da cultura contemporânea que interliga conteúdos e saberes das mais diversas áreas. Essa intertextualidade, como analisa Escalante (2016), requer letramentos múltiplos dos interagentes para apreender a vasta gama de referências emprestadas de produtos como filmes, seriados televisivos e games, configurando-se, assim, também como bens culturais do entretenimento (KNOBEL; LANKSHEAR, 2007) que despertam e/ou exigem competências cognitivas para sua fruição.

Alicerçada nessa lógica, a autora pontua que os memes estariam instituindo novas formas de letramento na rede digital, ao estimular práticas interacionais pautadas no aprendizado, leitura e escrita, demandas cognitivas primordiais para a interpretação e decodificação e compreensão destas produções.

Shifman (2013) analisa as relações de literacia e intertextualidade articuladas nos memes, bem como as disputas simbólicas em torno do capital social, uma vez que diferentes gêneros de meme envolvem variados níveis de habilidades cognitivas. Assim, alguns destes objetos podem ser entendidos (e criados) pela maioria das pessoas, enquanto outros exigem conhecimento detalhado sobre uma subcultura memética específica, havendo a diferenciação entre aqueles que estão "por dentro" e são, portanto, parte da comunidade e aqueles que são outsiders. Seguindo tal lógica, Jenkins, Ford e Green (2014, p.44) pontuam que "quando membros do público escolhem retransmitir textos de mídia, eles demonstram que pertencem a uma comunidade, que estão in em relação à referência e compartilham alguma experiência em comum".

Já a relação interdiscursiva dos memes com produtos culturais e seus fãs nas redes por meio do consumo de humor, sociabilidade e interação, também tem ocupado espaço de destaque nos estudos recentes. Uma vez que, com o potencial de desdobramento narrativo que marca os memes, a interpretação de uma única versão pode exigir referências contínuas a um universo próprio (inclusive aquele apreendido a partir do universo diegético de um produto da cultura pop) para que possa ser compreendido o se conteúdo. É possível, assim, também constatar o 


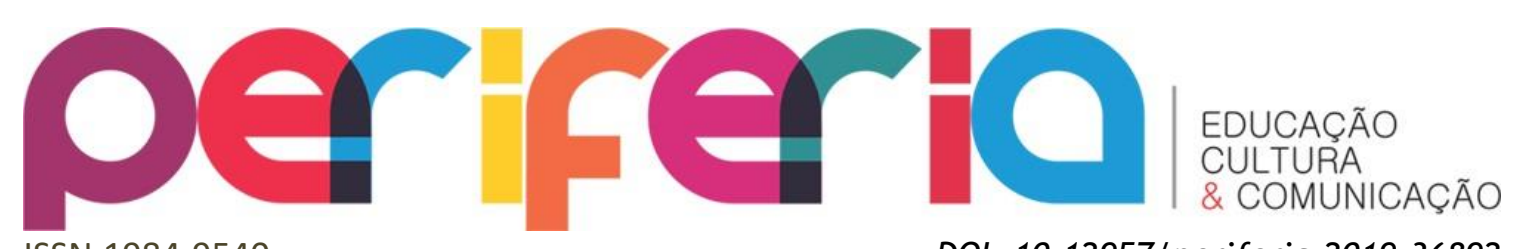

ISSN:1984-9540

surgimento de gêneros estéticos entre os memes (INOCÊNCIO, 2017), incluindo-se também os formatos circunscritos nas matrizes da linguagem.

Relacionando as culturas de fãs ao debate público, Milner (2016) traz importantes contribuições para os estudos dos memes digitais ao analisar como processos, identidades e políticas se entrelaçam nos discursos dos memes. Para o autor, ao inserir-se em subculturas meméticas, é demandado aos interagentes a apreensão de certos repertórios, ou letramentos (também chamados aqui de literacias). Assim, para criar variações meméticas inovadoras e realmente cômicas contextualizadas a determinado tema que é debatido naquela comunidade digital, é essencial compreender os processos que os orientam, como fluência no reconhecimento de referências culturais e ter competências cognitivas (letramento). Uma vez proficientes nesses processos, os interagentes poderiam de fato contribuir de forma mais transformadora, constituindo parte de um público plural e diverso, com lutas representacionais estruturando uma polivocalidade, ou amplas visões sobre um mesmo debate.

Ainda que para os participantes criarem e circularem memes como elementos discursivos em subculturas seja demandado certo nível de literacia para decodificálos e interpretá-los, esse letramento transformador, poderia, assim, permitir que os atores sociais participem mais ativamente no discurso público, contribuindo com diversas perspectivas que democratizem o debate, utilizando os memes como uma língua franca ${ }^{6}$ relacional para engajar-se em diálogos sobre políticas públicas e negociar o valor de identidades, vozes e posicionamentos.

\section{MEMES, LETRAMENTO E APRENDIZADO SOCIAL EM GAME OF THRONES DA DEPRESSÃO}

Game of Thrones é uma ficção seriada televisiva estadunidense criada por David Benioff e D. B. Weiss e lançado em abril de 2011 pelo o canal de TV a cabo

\footnotetext{
${ }^{6}$ Língua franca ou língua de contato é um dialeto comum que determinada comunidade multilíngue adota ou desenvolve, de modo que seja possível comunicar-se de forma coletiva, sendo esta geralmente adversa às demais línguas-mãe faladas pelo grupo.
} 


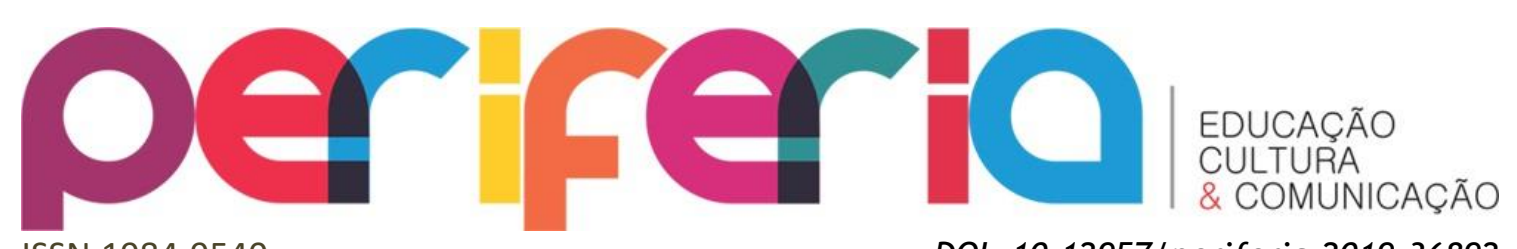

ISSN:1984-9540

DOI: 10.12957/periferia.2019.36892

HBO. Baseada na saga de livros intitulada A Song of Ice and Fire (As Crônicas de Gelo e Fogo), do escritor George R.R. Martin, a série que relata disputas pelo poder dos sete reinos de Westeros, um universo medieval e com seres fantásticos. Além dos longos diálogos e dos planos abertos e cinematográficos, Game of Thrones traz um enredo complexo e estruturado de maneira multiplot, uma forma de narrativa que comporta múltiplas tramas entrecruzadas, com núcleos e personagens igualmente importantes dentro de uma mesma história.

Assim como a saga de livros, a série, que em 2019 estreará sua oitava e última temporada, é carregada de elementos-surpresa que incitam nos fãs - tanto os espectadores do seriado quando os leitores dos livros - variadas expectativas a respeito de quais serão as reviravoltas que ocorrerão ao longo de cada episódio, oscilando entre momentos de drama, violência, suspense, horror, aventura e romance. Tais elementos costumam elencar a série ao topo dos temas mais discutidos ao redor de todo o mundo nos principais sites de redes sociais, como Twitter, Instagram e, principalmente, Facebook, foco da investigação aqui empreendida.

Nesse contexto, realizaremos uma análise de conteúdo exploratória a partir das amostras de imagens postadas como comentários, que foram coletadas na página de Facebook Game of Thrones da Depressão, ou GOT da Depressão, criada em 2013 e que atualmente possui quase 700 mil seguidores, tornando-se bastante popular ao ironizar pequenos momentos de decepção experienciados pelos fãs com a série.

As publicações da página GOT da Depressão no Facebook comentam sobre cenas dos episódios mais recentes, sobre personagens, e novidades do elenco através de postagens em textos e montagens imagéticas peculiarmente carregadas de humor irônico e spoilers, satirizando as previsibilidades, as adaptações e divergências entre livro-série e as quebras de expectativa dos fãs. Uma característica notável é que a página sempre traz uma intensa quantidade de referências à trama por meio de duplo sentido e ironia, em sua maioria a apreensão e interpretação só são possíveis para quem realmente é fã da saga literária e televisiva e está atualizado com o conteúdo. 


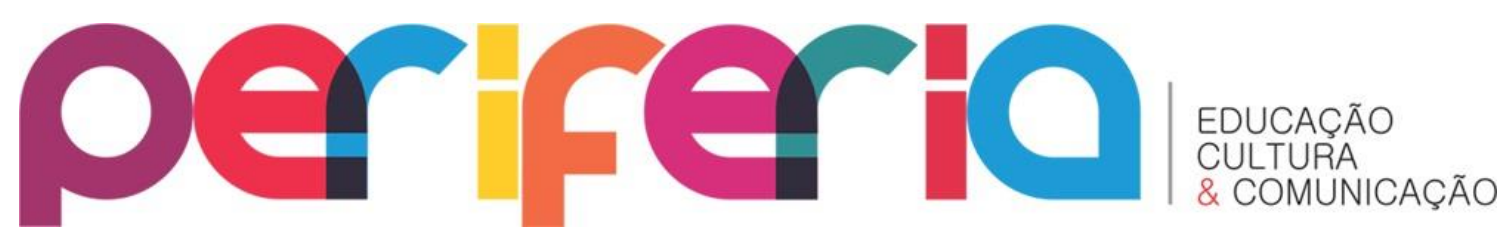

ISSN:1984-9540

DOI: $10.12957 /$ periferia.2019.36892

Figura 1 - Comentários com imagem em uma postagem da página Game of Thrones da Depressão.
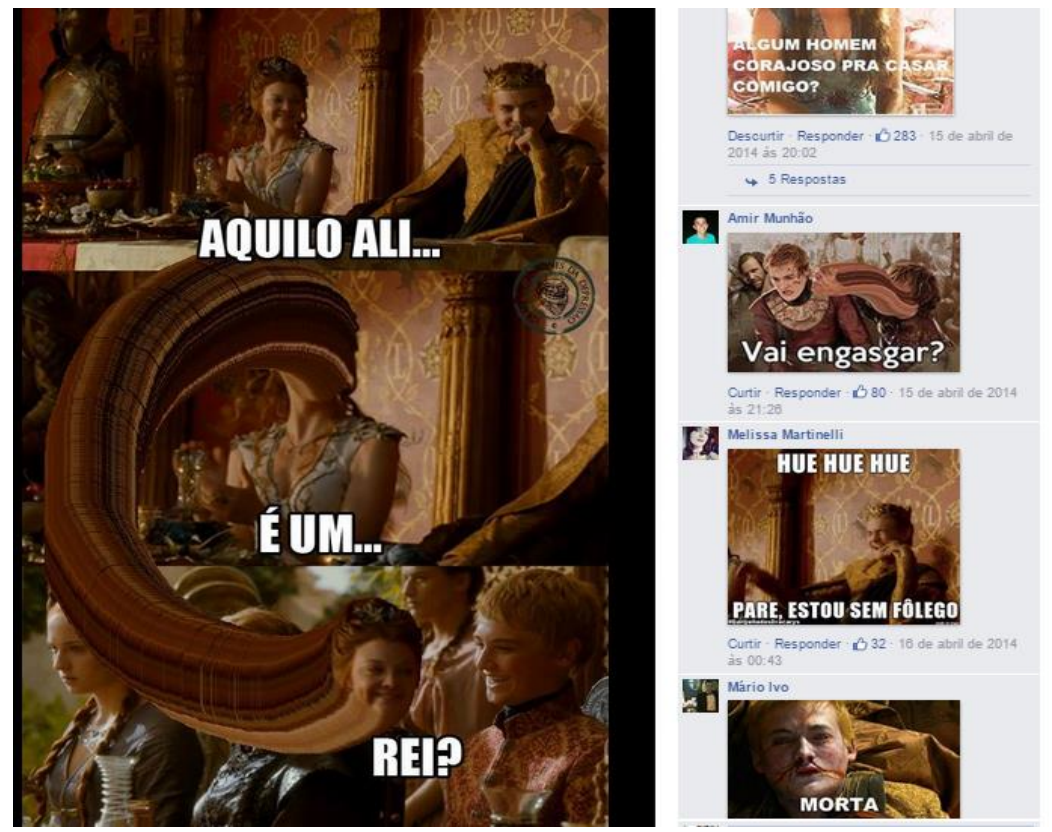

Fonte: <Fb.com/GOTdaDepressaoll>. Acesso em: 22 ago. 2018.

Nesse contexto, o repertório interpretativo (POTTER; WETHERELL, 1987 apud FONTANELLA, 2012) figura como um conjunto de termos e metáforas que são frequentemente referenciados por membros de uma comunidade para definir e analisar ações ou eventos. Quando aplicada em comunidades digitais, essa sintaxe de metáforas compartilhadas através da "apropriação criativa pela edição e replicação de textos, imagens e vídeos na forma de mashups, remixagens e memes torna-se uma prática importante para fazer referência ao imaginário compartilhado" (FONTANELLA, 2012, p. 5), aproximando os fãs em um processo identitário.

A página GOT Depressão é, assim, uma rica amostra da intimidade desses fãs de GOT com o seriado: eles conhecem o universo ficcional, seus personagens, históricos, cenas e através da interação e do humor aprendem a remontar diálogos, se apropriar de fotos de cenas e inserir legendas para aplicá-las a outro contexto, respondendo frequentemente com comentários em forma de piada ou imagens meméticas que também são piadas. As versões destes memes dependem da ação 


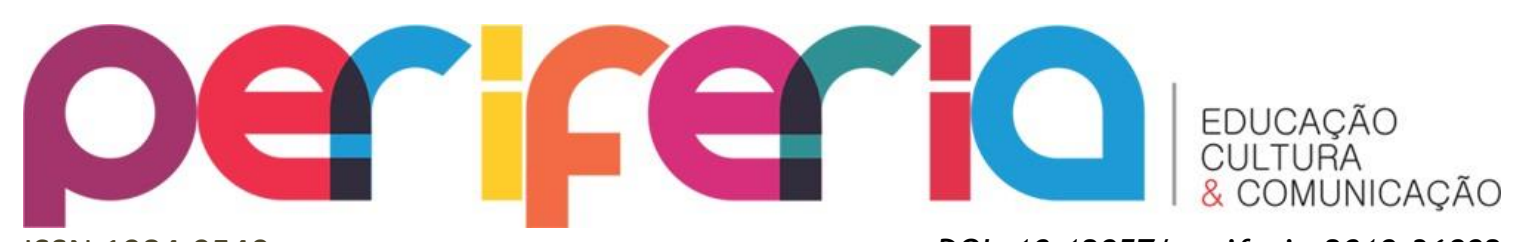

ISSN:1984-9540

DOI: $10.12957 /$ periferia.2019.36892

criativa, habilidades intertextuais e metalinguísticas dos interagentes, frente a um amplo leque de possibilidades oferecidas pela piada original, o material simbólico e audiovisual da série.

As imagens abaixo (figura 2) são um meme em específico que circula bastante nos comentários das páginas, tendo algo em comum: todas estão simulando um "like" (ou botão "curtir" do Facebook) de diversos personagens, como o primeiro deles, que traz algumas cores do movimento LGBTQ+ e a legenda "Renly Baratheon achou fabulous", referindo-se a um personagem que desenvolve relações homoafetivas e estereotipando seu comportamento como afeminado, através do vinculo a um ícone visual e um termo (fabulous) reconhecidamente gays. Já os demais exemplos do like, fazem referência às mortes e mutilações sofridas por alguns personagens: a segunda e terceira imagens dizem respeito a Jaime Lannister, que teve a mão direita cortada e depois substituída por uma mão de ouro puro.

Figura 2 - Memes do botão "curtir” na página Game of Thrones da Depressão.

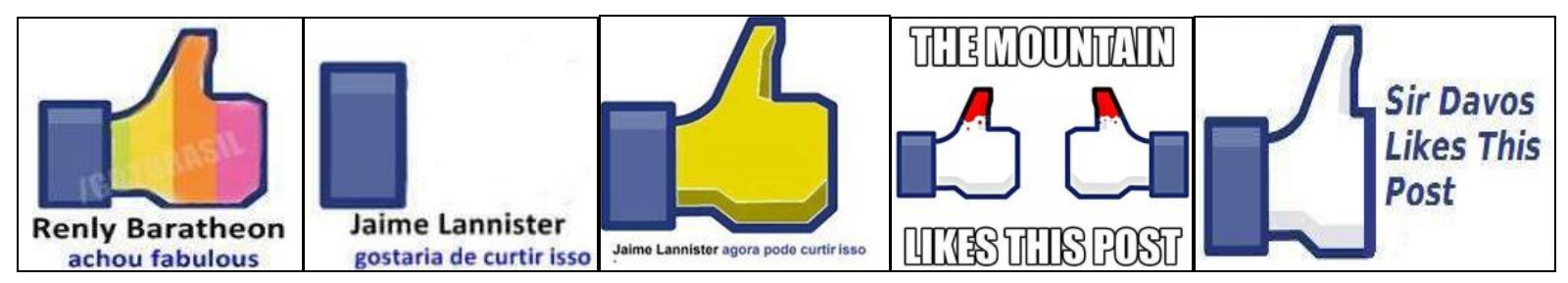

Fonte: <Fb.com/GOTdaDepressaoll>. Acesso em: 22 ago. 2018.

$\mathrm{Na}$ segunda imagem, a mão do ícone like está ausente, adicionada da legenda "Jaime gostaria de curtir isso" (ironizando que ele não pode, pois não tem mais mão). No terceiro like, a mão está amarela e a legenda é "Jaime Lannister agora pode curtir isso" ou seja, após ganhar substituir a original pela mão dourada. O quarto like refere-se ao personagem Montanha, que durante um combate, esmagou o crânio de seu oponente Oberyn Martell com os dois polegares. Por fim, a última imagem refere-se a Sir Davos, personagem que teve a ponta dos dedos da mão esquerda cortados como punição pelos crimes cometidos no passado como contrabandista e por isso o ícone do like aparenta não ter dedos. Como visto, esses 


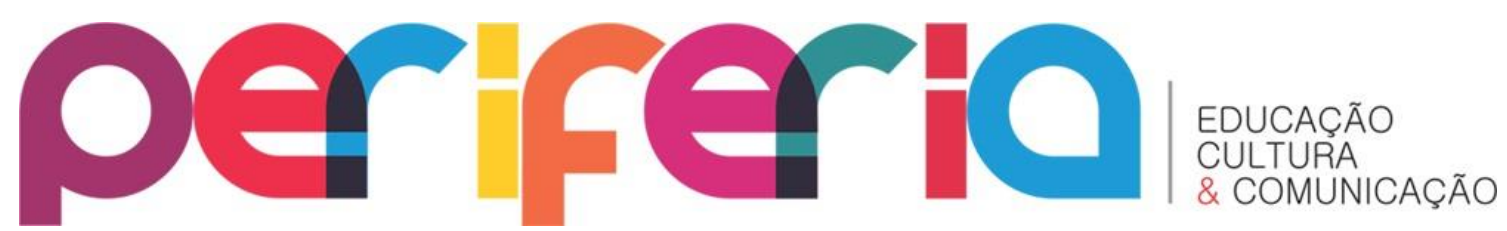

likes são uma maneira de incorporar esse universo ficcional de modo irônico e memético à plataforma específica do Facebook, em seus mecanismos de interação (o curtir) e seus ícones (a mão com polegar).

Nos comentários tecidos pelos interagentes na amostra da figura 2 e também da figura 3 a seguir, podemos observar uma extensão com a linguagem hipertextual em diferentes sentidos da piada inicial. Mas para compreendê-las e em seguida aprender a desdobrá-las, primeiro é necessário saber quem são os personagens ilustrados. Secundariamente, é preciso lembrar-se do histórico dos personagens, nesse caso em específico, de suas mortes e mutilações trágicas. Ainda, há que se construir a relação entre esses fatos para então entender seu humor, assimilação geralmente feita quase que instantaneamente pelos seguidores da página, acostumados com seu universo cultural referente, seu tom afinado de humor irônico.

Figura 3 - Memes que satirizam mortes/mutilações dos personagens com duplo sentido.

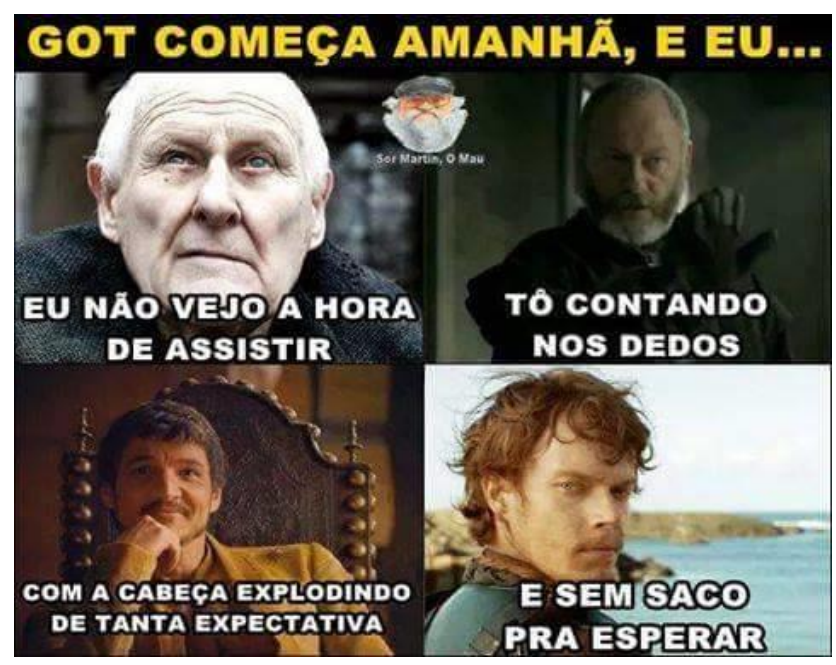

Fonte: <Fb.com/GOTdaDepressaoll>. Acesso em: 22 ago. 2018.

Para compreender o potencial irônico da postagem na figura 3 e o respectivo diálogo tecido através das imagens meméticas nos comentários, é necessário que o interagente recorra a seu conhecimento de mundo e à sua capacidade metalinguística de interpretação e organização das ideias; ou seja, são fundamentais a intertextualidade e o interdiscurso. Por meio de diversos 


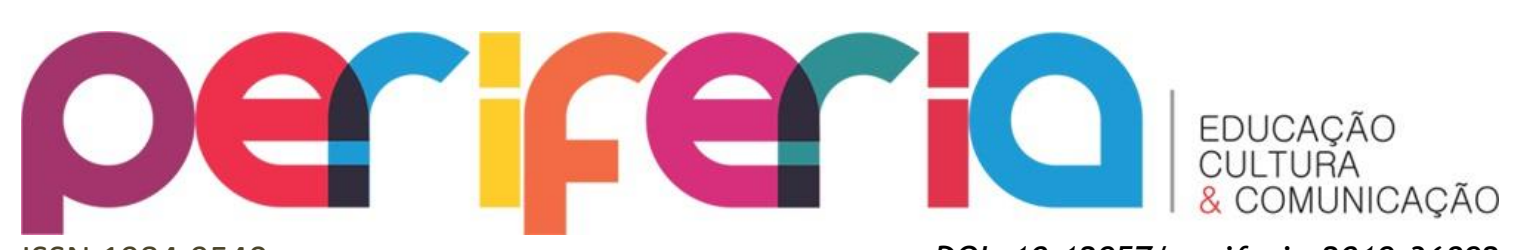

trocadilhos com duplo sentido, a imagem traz algumas montagens agrupadas e o título: GOT começa amanhã, e eu... Eu não vejo a hora de assistir (legenda sobre a imagem de Aemon Targaryen, que é cego); Tô contando nos dedos (imagem de Sir Davos, que não tem as pontas dos dedos); Com a cabeça explodindo de tanta expectativa (imagem de Oberyn Martell que teve o crânio esmagado); e sem saco pra esperar (imagem de Theon Greyjoy, que foi castrado).

A partir destes exemplos iniciais, desenvolvemos o raciocínio de que um imaginário específico é reconhecido e intensamente vivenciado por meio do aprendizado social pelos interagentes que produzem, consomem e circulam memes na página GOT da Depressão, servindo tal imaginário, assim, de substrato para vários memes. Os letramentos envolvidos na apropriação criativa de produtos culturais transformados em memes como estes, ressignificando os acontecimentos e cenas da trama, demonstra que os interagentes que produzem os memes utilizam-se da ironia para estruturar coletivamente uma experiência lúdica de consumo e interpretação do produto cultural.

As imagens abaixo se configuram como metamemes, ou seja, memes que fazem referência a outros memes, uma ideia que é aprendida e repetida, representando outra do mesmo gênero. Em um contexto de autorreferência, as imagens tomam o enredo de alguns protagonistas da série para personalizar memes já existentes. O primeiro, faz relação ao guerreiro Khal Drogo, morto devido a uma infecção no peitoral, lugar em que o personagem do meme original pousa a mão. 0 segundo meme, "isso só pode ser obra do cão", substitui a imagem do animal fantasiado de pedreiro pela do personagem Sandor Clegane, apelidado de Cão de Caça na série, com um capacete de segurança usado em obras e o que parece ser um projeto arquitetônico. 


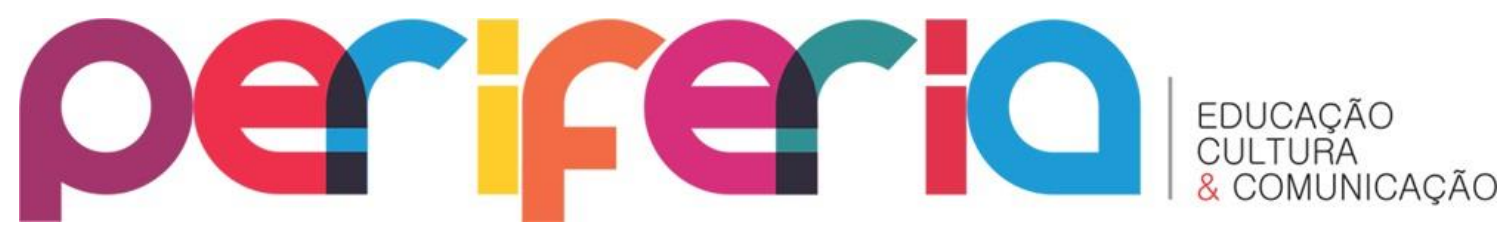

ISSN:1984-9540

DOI: $10.12957 /$ periferia.2019.36892

Figura 4 - Metamemes e suas referências na página Game of Thrones da Depressão.
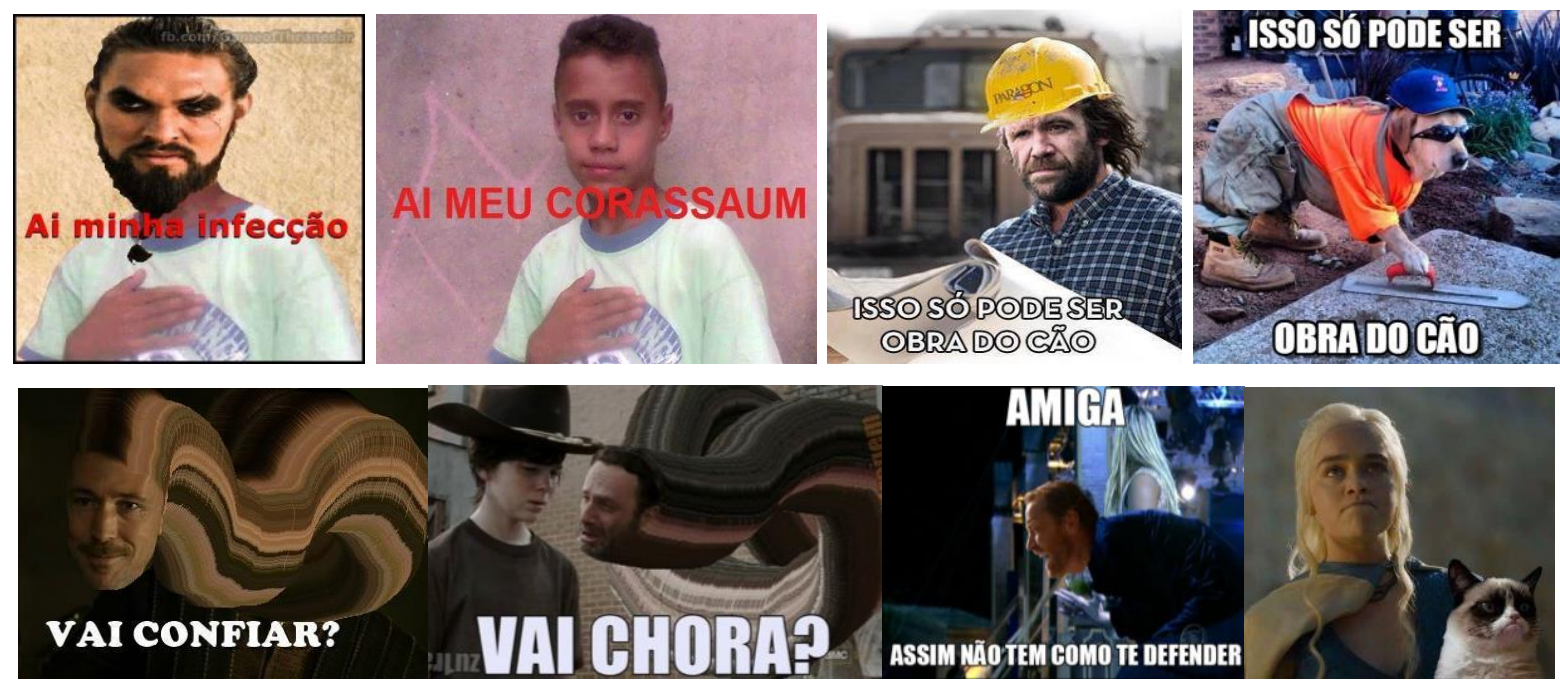

Fonte: <Fb.com/GOTdaDepressaoll>. Acesso em: 22 ago. 2018.

Na figura 4, o meme "vai chora?" (sic) é originado de uma cena da série The Walking Dead em que o ex-xerife Rick Grames está chorando desolado ao saber da morte de sua esposa ao dar à luz e seu filho Carl, que a matou para evitar que esta se tornasse zumbi, permanece contido. No meme, a cabeça de Rick soa provocativa questionando Carl se ele vai chorar. Na mesma lógica, o personagem Petyr Baelish é famoso por arquitetar grandes intrigas durante a série e seu meme em comparação ao original questiona “vai confiar?”. Outros memes que se baseiam em outro meme mostram uma montagem do meme "amiga, assim não tem como te defender", originado do reality show A Fazenda, mas nesse caso, com o rosto do escudeiro de Daenerys Targaryen, Jorah Mormont, que foi postado em resposta a uma postagem que comentava sobre alguns deslizes que a rainha estaria cometendo ao governar na trama. Por fim, um meme que traz a própria Daenerys com expressão semelhante à do conhecido felino Grumpy Cat, que ganhou popularidade na internet devido a sua expressão facial aparentemente sempre irritada.

Já o videomeme Deal With It (lide com isso) consiste em pegar alguma cena ou momento em que personagens ou celebridades tenham sido desmoralizados publicamente, por meio do famoso “fora”. Quando o protagonista que desmoraliza o outro(a) está realizando o ato, um par de óculos escuros aparece em quadro, vai 


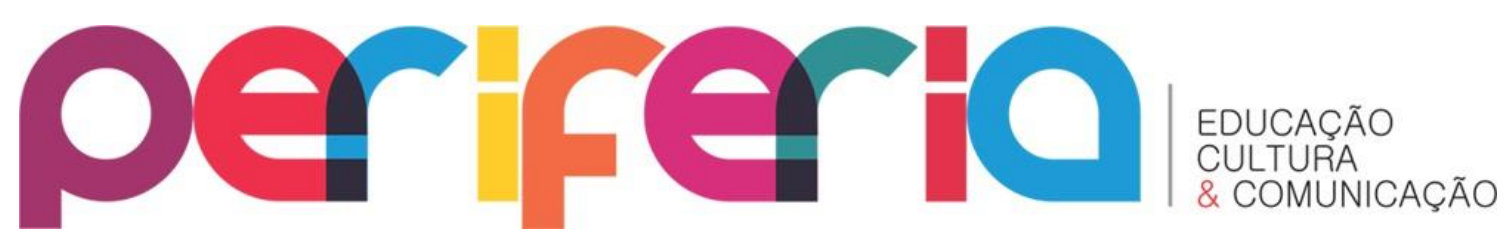

descendo e para sobre o rosto do protagonista. Uma versão Deal With It compartilhada em Game of Thrones da Depressão traz uma cena do quarto episódio da terceira temporada do seriado, em que a personagem Daenerys Targaryen (também chamada de Khaleesi) negocia com um mercador o exército de escravos conhecido por "Imaculados" em troca de um dos dragões que possui".

Por estar em terras de outra cultura, ao longo de todo o episódio, uma das seguidoras de Khaleesi esteve traduzindo o diálogo entre ela e o mercador, que esteve xingando-a e referindo-se a Daenerys de forma desrespeitosa. Na cena, após realizar a troca, o mercador pede agressivamente para a intérprete dizer a Khaleesi que o dragão não the obedece. Ao que a própria Daenerys responde no idioma dele "um dragão não é um escravo". Ao surpreendê-lo por dominar o idioma, ela o informa que se trata da sua língua materna (portanto ela sempre a conhecera, mas fingira que não e o tempo inteiro pôde ouvi-lo desrespeitando-a). Em seguida, a Targaryen ordena ao exército recém-adquirido que mate todos os mestres que os aprisionavam, ao que o mercador tenta ordená-los a matá-la. Então a protagonista pronuncia "dracarys", um comando para o seu dragão cuspir fogo no mercador, queimando-o vivo.

${ }^{7}$ Disponível em: <https://www.youtube.com/watch?v=gvGd5hq5ghw>. Acesso em: 22 ago. 2018. 


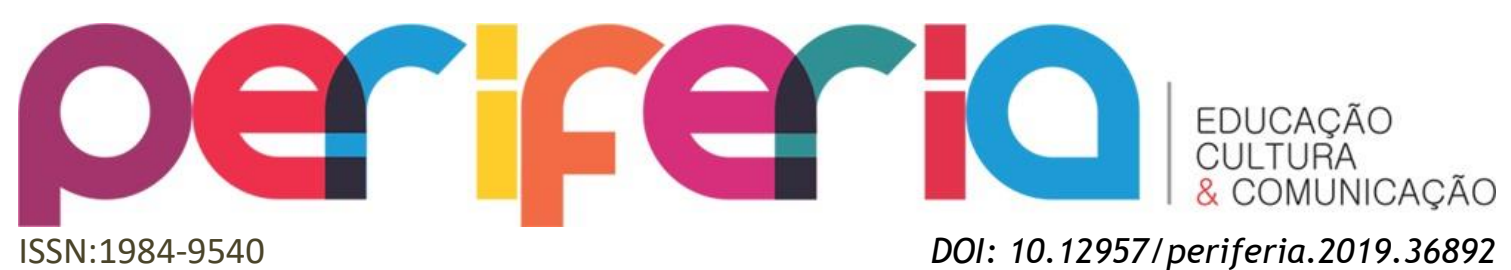

Figura 5 - Frames do videomeme Daenerys Deal With It.

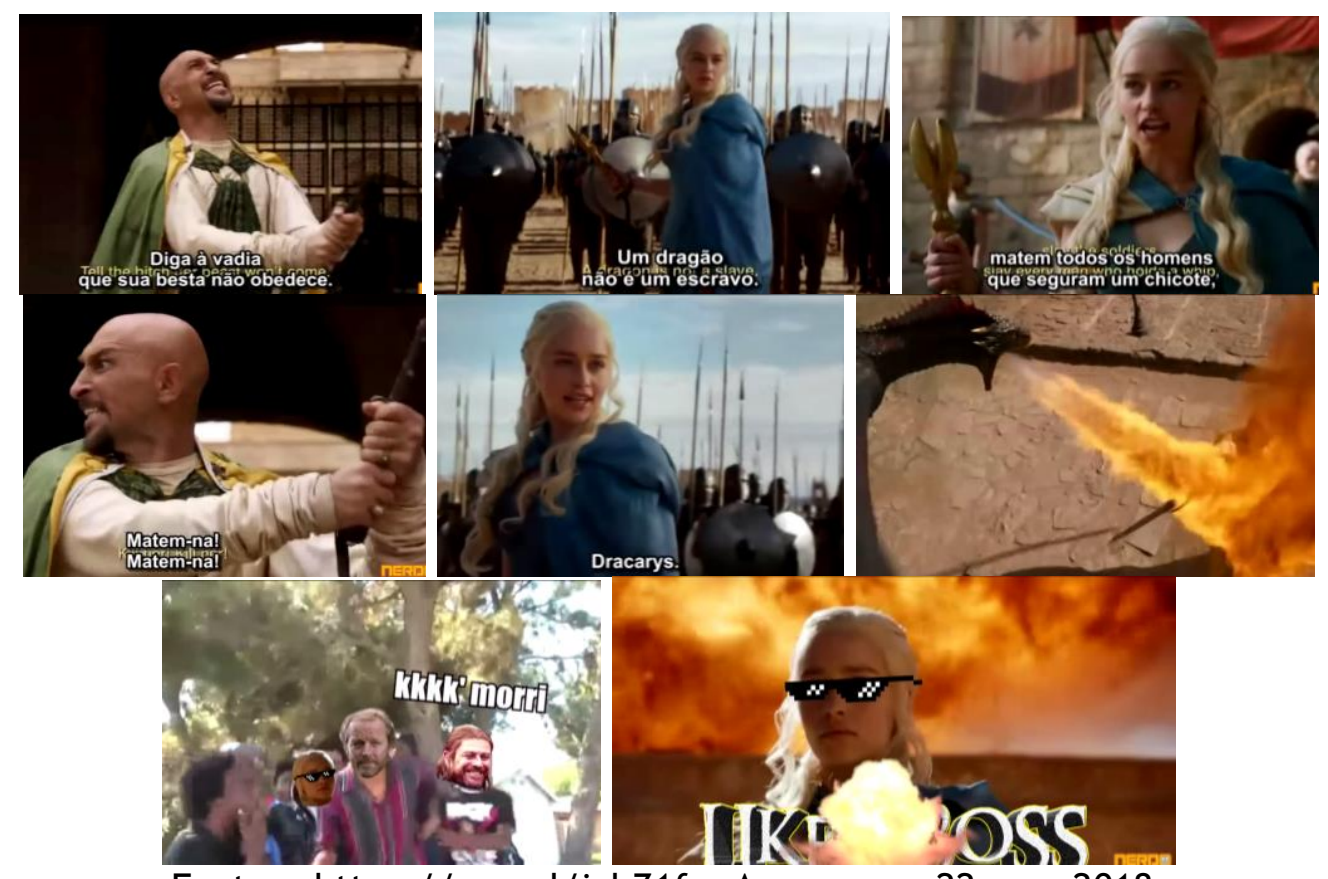

Fonte: <https://goo.gl/icbZ1f>. Acesso em: 22 ago. 2018.

Então a cena corta para os rappers comemorando, um deles com o rosto de Daenerys, outro pelo de seu escudeiro Jorah Mormont e outro pelo do personagem Ned Stark - que foi decapitado ainda na primeira temporada - sorrindo e acompanhado da legenda “kkkk' morri”, uma maneira irônica e ambígua de referenciar sua morte com a tradicional expressão para indicar grande surpresa, choque ou crise de risos. Por fim, surge ainda uma última cena em que Daenerys aparece com o óculos escuro característico do meme Deal With It e a legenda "Like a boss" - um meme verbal bastante popular que indica alguém que realizou uma grande façanha, "como um chefe" - em primeiro plano e ao fundo surgem as chamas da cidade sendo queimada por seus dragões. Outras versões do meme Deal With It com cenas de Game of Thrones podem ser encontradas, como uma interpretada pela Rainha Mãe Cersei e seu irmão Tyrion Lannister 8 e outra montagem também com Cersei e o Lorde Petyr Baelish?.

Caracterizadas por Knobel e Lankshear (2015, p. 94) como "espaços de afinidades", tais comunidades online reúnem participantes que desenvolvem entre

\footnotetext{
${ }^{8}$ Disponível em: <https://www.youtube.com/watch?v=amj_uA98S2U>. Acesso em: 22 ago. 2018.

${ }^{9}$ Disponível em: <https://www.youtube.com/watch?v=OFIOCZ-bMsl>. Acesso em: 22 ago. 2018.
} 


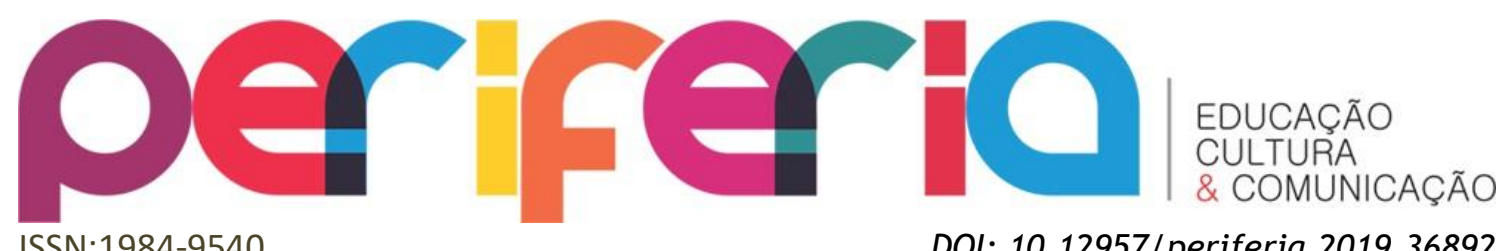

ISSN:1984-9540

DOI: 10.12957/periferia.2019.36892

si práticas de aprendizagem social, seja no interpretar, compartilhar ou criar materialmente estes memes.

A aprendizagem social ocorre em contextos de 'interações estáveis, especialmente com outros, em torno de problemas ou ações', nos quais há coisas a serem feitas, conhecidas, entendidas e dominadas. A aprendizagem social é colaborativa, no sentido de que os participantes falam (escrevem etc.) sobre o que eles estão fazendo e tentando entender, conseguindo compreender conceitos, princípios e procedimentos por meio de suas interações e comunicação. Envolve também 'aprender a ser' um participante completo no campo, pela aquisição das práticas e normas (...) estabelecidos nesse campo, isto é, tornando-se como um destes (...)

Além de interagir uns com os outros, os sujeitos nestes espaços assumem identidades com traços em comum, as apresentam de forma lúdica e interagem ativamente em uma "comunidade de práticas" específicas. Assim, Knobel e Lankshear (2007) compreendem os memes enquanto fenômenos culturais e novas práticas de letramento, a partir do momento em que aglutinam elementos de determinadas culturas e os ressignificam por meio da intertextualidade em variadas matrizes de linguagens, rejuntando os participantes que nestas comunidades socializam por meios da literacia nestes processos.

\section{CONSIDERAÇÕES FINAIS}

Como observado na análise, os fãs da página GOT da Depressão frequentemente interagem através do acréscimo de imagens meméticas em comentários, nos quais alimentam as piadas em relação a personagens ou acontecimentos, suas expectativas sobre o desenrolar da narrativa e a formulação de teorias sobre os mistérios da trama. Aprender a recriar tais histórias de acordo com as normas estéticas e discursivas convencionadas na comunidade, a partir de um novo ponto de vista, é um processo que convoca a agência de variados letramentos - seja para manipular suas materialidades gráficas e audiovisuais, no contexto social da usabilidade e engajamento por meio destas TICs ou a habilidade cognitiva de traduzir e ressignificar referências narrativas intertextuais. 


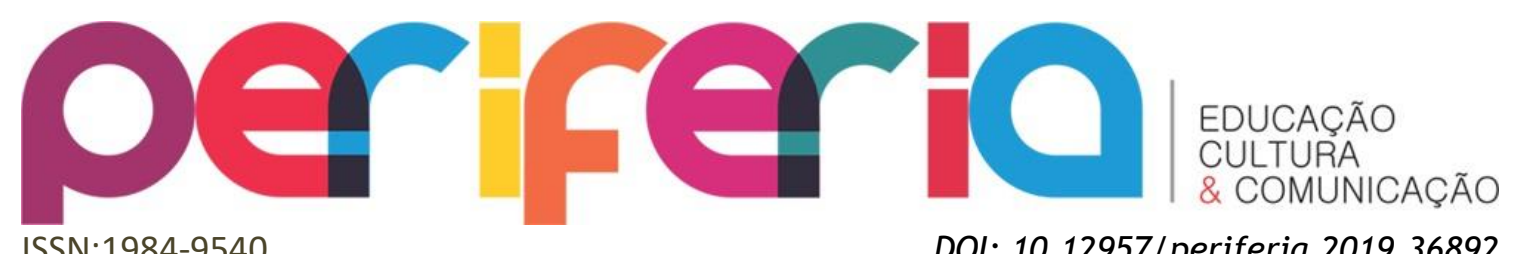

ISSN:1984-9540

DOI: 10.12957/periferia.2019.36892

Esse processo de síntese memética, ressignificação da imagem e sua subversão de contexto sob a ótica da cultura participativa, podem ser considerados como formas de produção de capital simbólico em busca de reputação e popularidade dos atores sociais na rede. $\mathrm{Na}$ base dessa relação de proximidade e representação social na cibercultura, implícitas na ordem da estética emitida pelos assuntos frequentemente satirizados nos memes, estão ainda o amadorismo e o deslocamento da preocupação quanto à perfeição estética para suas capacidades de simbiose e conexão a temas do cotidiano.

Assim, o imaginário aprendido e reproduzido em relação ao universo diegético da série pode ser identificado de modo latente no conjunto de referências e metáforas analisado. O repertório da experiência individual de assistir TV, quando debatido coletivamente por meio dos memes, serve como substrato para ressignificar tais representações midiáticas. No tocante ao ensino e à promoção do letramento hipertextual, percebeu-se a necessidade de repensar as práticas de ensinar e aprender, pois letramento engloba outros múltiplos que, para consolidação, precisam da inserção de novos métodos de ensino que se valham de novas tecnologias e novas formas de aplicação das linguagens.

\section{REFERÊNCIAS}

BAKHTIN, Mikhail. Estética da criação verbal. Tradução de Paulo Bezerra. $6^{\mathrm{a}}$ ed. São Paulo: WMF Martins Fontes, 2011.

CAVALCANTE, Mônica Magalhães. Os sentidos do texto. São Paulo: Contexto, 2013.

DAWKINS, Richard. O gene egoísta. Belo Horizonte: Editora Itatiaia, 2001.

ELLISON, Nicole; BOYD, Danah. Sociality through social network sites. In: The Oxford Handbook of Internet Studies. Oxford: Oxford University Press, 2013.

ESCALANTE, Pollyana. O potencial comunicativo dos memes: formas de letramento na rede digital. 2015. 120 f. Dissertação (Mestrado em Comunicação) - Universidade do Estado do Rio de Janeiro, Rio de Janeiro, 2015.

FONTANELLA, Fernando. Memes como Consumerismo: O Caso de Mass Effect 3. In: Anais do XXXV Congresso Brasileiro de Ciências da Comunicação. São Paulo: Intercom, 2012. 


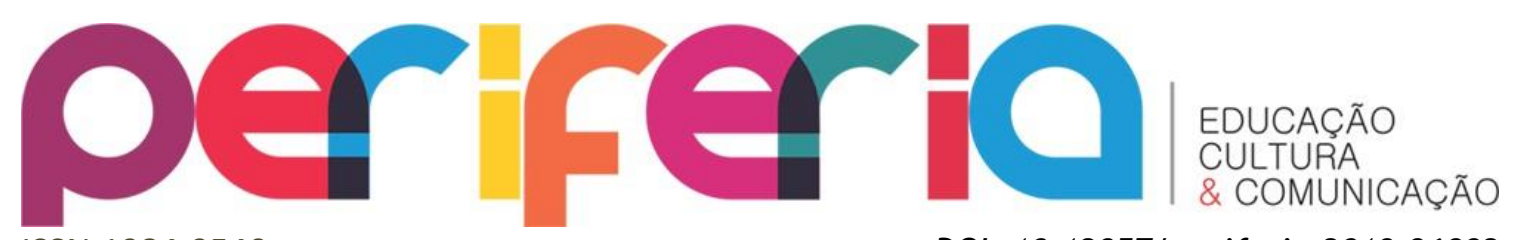

ISSN:1984-9540

DOI: 10.12957/periferia.2019.36892

INOCÊNCIO, Luana. May the memes be with you: uma análise das teorias dos memes digitais. In: Anais do IX Simpósio de Pesquisadores em Cibercultura ABCiber. São Paulo: ABCiber, 2017. Disponível em: <https://goo.gl/fWjcQF>. Acesso em: 22 ago. 2018.

JENKINS, Henry. Cultura da convergência. São Paulo: Aleph, 2008.

JENKINS, Henry; GREEN, Joshua; FORD, Sam. Cultura da conexão: criando valor e significado por meio da mídia propagável. São Paulo: Aleph, 2014.

KNOBEL, Michele; LANKSHEAR, Colin. Online Memes, affinities and cultural production. In: KNOBEL, Michele; LANKSHEAR, Colin. A new literacies sampler. New York: Peter Lang, 2007.

KNOBEL, Michele; LANKSHEAR, Colin. Aprendizagem social e novas tecnologias. In: ROMANCINI, Richard (entrevista). Comunicação \& Educação, vol. 20, n. 1, 91-103, 2015. Disponível em:

<https://doi.org/10.11606/issn.2316-9125.v20i1p91-103>. Acesso em: 22 ago. 2018.

LOBO-SOUSA, Ana Cristina; ARAÚJO, Júlio César; PINHEIRO, Regina Cláudia. Letramentos que emergem da hipertextualidade. In: ARAÚJO, Júlio César; DIEB, Messias (Orgs.). Letramentos na Web: gêneros, interação e ensino. Fortaleza: Edições UFC, 2009.

MILNER, Ryan. The world made meme: Public Conversations and Participatory Media. Cambridge: MIT Press, 2016.

POTTER, Jonathan e WETHERELL, Margaret. Discourse and Social Psychology: Beyond Attitudes and Behaviour. Londres: SAGE Publications, 1987.

PRIMO, Alex. Interações em rede. Porto Alegre: Sulina, 2013.

ROJO, Roxane Helena Rodrigues. Pedagogia dos multiletramentos. In: ROJO, Roxane Helena Rodrigues; MOURA, Eduardo. Multiletramentos na escola. São Paulo: Parábola Editorial, 2012.

SHIFMAN, Limor. Memes in digital culture. Cambridge: MIT Press, 2013.

SILVEIRA, Stefanie. A cultura da convergência e os fãs de Star Wars: um estudo sobre o Conselho Jedi. Dissertação de Mestrado/UFRGS. 2010.

STREET, Brian. Letramentos sociais: abordagens críticas do letramento no desenvolvimento, na etnografia e na educação. Tradução de Marcos Bagno. São Paulo: Parábola Editorial, 2014. 


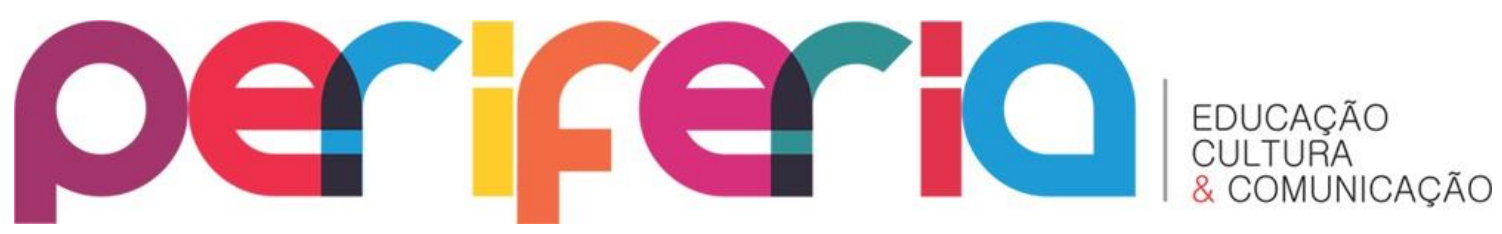

XAVIER, Antonio Carlos. Leitura, texto e hipertexto. In: MARCUSCHI, Luiz Antônio; XAVIER, Antonio Carlos. Hipertextos e gêneros digitais - novas formas de construção de sentido. 2. ed. Rio de Janeiro: Lucerna, 2005. 